\title{
APLIKASI PENGENALAN OBJEK WISATA SEJARAH KOTA TUA JAKARTA BERBASIS AUGMENTED REALITY
}

\author{
Agung Selamet Riadi ${ }^{1}$, Anton $^{2}$, Ummu Radiyah $^{3}$ \\ ${ }^{1,3}$ Teknik Informatika, STMIK Nusa Mandiri Jakarta, Manajemen Informatika, ${ }^{2}$ AMIK BSI Tangerang \\ 1,3 Jalan Kramat Raya No.18, Senen, Jakarta Pusat, ${ }^{2}$ Jalan Gatot Subroto Blok B No.8 Cimone, Tangerang \\ Telepon: 021-31908575 Fax: 021-31908565, Telepon 021-5527711 \\ E-mail: agungriadi20@gmail.com , anton@bsi.ac.id,ummu.urd@nusamandiri.ac.id
}

\begin{abstract}
The world of tourism in Indonesia, especially DKI Jakarta, has developed rapidly. One of the tourism object in Jakarta is Old Town tour (Kota Tua). About thirty percent of visitors who came to the Kota Tua area, generally come only to take pictures, bike or just gather. To provide a unique experience and historical knowledge to tourists, an application of augmented reality is made that can be used by tourists when visiting Jakarta's Kota Tua area. In the application created there are three-dimensional objects, photos, as well as general informations and historical informations of attractions in the Kota Tua Jakarta. The method of this research using waterfall model as a system development model with five stages namely Requirement Analysis, System Design, Implementation, Integration and Testing, Operation and Maintenance.
\end{abstract}

\section{Keyword: Museum, Historical Tourism, Old Town Tour, Kota Tua, Augmented Reality}

\section{PENDAHULUAN}

Dunia pariwisata di Indonesia khususnya di Daerah Khusus Ibukota (DKI) Jakarta telah berkembang dengan pesat. Di DKI Jakarta banyak sekali objek wisata dengan berbagai jenis seperti wisata religi, wisata kuliner, dan wisata sejarah. Salah satu objek wisata sejarah yang ada di wilayah DKI Jakarta adalah wisata Kota Tua Jakarta.

Kota Tua Jakarta merupakan kawasan penting dimasa penjajahan, kawasan ini mencakup sebagian wilayah Jakarta Barat dan Jakarta Utara. Pada zaman dahulu, Pelabuhan Sunda Kelapa merupakan pelabuhan terbesar dan tersibuk yang digunakan untuk kegiatan jual beli dalam kegiatan perdagangan internasional, sedangkan kawasan sekitar kawasan Museum Bank Indonesia dan Museum Fatahillah adalah salah satu pusat pemerintahan kolonial Belanda. Seiring berjalannya waktu, kini Kota Tua Jakarta dimanfaatkan sebagai tempat wisata bersejarah yang dapat memberikan informasi berharga tentang sejarah Kota Tua.

Di sekitar kawasan Kota Tua terdapat beberapa objek wisata yang dapat dikunjungi oleh wisatawan, diantaranya adalah Museum Fatahillah, Museum Seni Rupa dan Keramik, Museum Bank Indonesia, Museum Bank Mandiri, Museum Bahari, Museum Wayang, Stasiun Kota, Jembatan Kota Intan, dan Cafe Batavia. Sayangnya sebagian wisatawan kurang mendapatkan informasi akan objek wisata yang ada di kawasan Kota Tua, jadi umumnya pengunjung datang ke Kota Tua hanya untuk berfoto-foto dengan manusia patung, bersepeda atau sekedar berkumpul di satu atu dua tempat wisata saja. bahwa:
Sekitar tiga puluh persen dari pengunjung kawasan Wisata Kota Tua Jakarta Utara ternyata tidak mengetahui jika kawasan itu memiliki tiga museum yang dikelola oleh Pemerintah Provinsi DKI Jakarta dan dua dikelola oleh Bank Indonesia, dan Bank Mandiri.

"Museum dan Galeri Seni adalah lembaga penting tempat untuk menghabiskan waktu yang berkualitas untuk belajar bagi pengunjung sepanjang hidupnya, serta meningkatkan kualitas pengunjung melalui pengalaman seni dan budaya melalui teknologi baru dan inovatif seperti teknologi Augment Reality" (Dieck et al., 2016).

(Sikumbang, 2015) memaparkan bahwa, "Potensi pariwisata di Jakarta sesungguhnya lumayan besar. Disamping Kota Tua, Objek Taman Mini Indonesia, Monas, dan Ancol juga beberapa mall megah bisa menjadi daya tarik bagi wisatawan lokal dan mancanegara. Sayangnya, informasi tersebut tidak gampang diperoleh".

Berdasarkan Undang-Undang Republik Indonesia Nomor 10 Tahun 2009 menyebutkan bahwa, "Daya Tarik Wisata adalah segala sesuatu yang memiliki keunikan, keindahan, dan nilai yang berupa keanekaragaman kekayaan alam, budaya, dan hasil buatan manusia yang menjadi sasaran atau tujuan kunjungan wisatawan". Untuk memberikan pengalaman yang unik kepada wisatawan, informasi saja tidak cukup, butuh daya tarik wisata seperti gambaran nyata tiga dimensi (3D) dari bangunan objek wisata tersebut. Untuk mewujudkan hal tersebut, maka dibutuhkan teknologi Augment Reality yang dapat menggabungkan benda maya dua dimensi dan ataupun tiga dimensi ke dalam sebuah lingkungan nyata dan dapat diaplikasikan di perangkat mobile. 
Implementasi teknnologi Augment Reality (AR) pada pengenalan benda cagar budaya yang ada di Museum Zoologi dapat menjadi teknologi interaktif yang dapat digunakan sebagai sarana pengenalan benda cagar budaya pada masyarakat (Haryani \& Triyono, 2017).

Aplikasi dapat dirancang untuk membuat daya tarik wisata sekaligus membantu wisatawan dalam hal mendapatkan pengetahuan sejarah, info lokasi, serta jam operasional objek wisata tersebut dengan penggambaran nyata atau menampilkan objek 3D bangunan yang nantinya akan membuat pengalaman yang lebih menarik untuk wisatawan yang ingin mengetahui atau sedang berkunjung ke tempat wisata Kota Tua Jakarta, sehingga penulis mengangkat tema penelitian: "APLIKASI PENGENALAN OBJEK WISATA SEJARAH KOTA TUA JAKARTA BERBASIS AUGMENTED REALITY". Manfaat dari penelitian ini adalah 1) Membuat aplikasi yang dapat diterapkan dalam pengenalan objek wisata kawasan Kota Tua Jakarta. 2) Membuat aplikasi yang dapat memberikan informasi yang jelas tentang objek wisata yang ada di kawasan Kota Tua Jakarta. 3) Memberikan daya tarik tersendiri dengan pengalaman yang unik kepada wisatawan dalam melakukan kunjungannya ke objek wisata di kawasan Kota Tua Jakarta.

\section{METODE}

Metode pengumpulan data yang penulis lakukan untuk menunjang dalam penelitian ini, antara lain:

\subsection{Teknik Pengumpulan data}

Teknik pengumpulan data untuk menunjang penelitian sebagai berikut:

\section{Observasi}

Melakukan observasi di kawasan Kota Tua Jakarta, dengan melihat secara langsung keadaan atau aktifitas wisatawan yang sedang berkunjung atau berwisata di kawasan Kota Tua Jakarta. Observasi dilakukan di beberapa tempat wisata yang berada di kawasan Kota Tua.

2. Wawancara

Melakukan wawancara terhadap beberapa wisatawan dan pegawai pada beberapa tempat wisata yang berada di kawasan Kota Tua yang nantinya hasil jawaban dari wisatawan dan pegawai tersebut dapat dijadikan sebagai bahan dasar dalam menyelesaikan masalah yang ada.

3. Studi Pustaka

Untuk mendukung materi dari penelitian ini, penulis melakukan pengumpulan bahan materi dengan mempelajari jurnal-jurnal, buku atau literatur yang berhubungan dengan masalah yang akan diteliti.

\subsection{Metode Pengambangan Aplikasi}

Penulis menggunakan metode model waterfall sebagai metode pengembangan aplikasi. Tahapan metode waterfall ini sebagai berikut:

\section{Requirement Analysis}

Pada tahap ini pengembang sistem memerlukan suatu komunikasi yang bertujuan untuk memahami software yang diharapkan pengguna dan batasan software. Informasi ini dapat diperoleh melalui wawancara, survey atau diskusi. Informasi tersebut dianalisis untuk mendapatkan data yang dibutuhkan oleh pengguna.

\section{System Design}

Pada tahap ini, desain sistem dapat membantu dalam menentukan perangkat keras, sistem persyaratan dan juga membantu dalam mendefinisikan arsitektur sistem secara keseluruhan.

3. Implementation

Pada tahap ini sistem pertama kali dikembangkan di program kecil yang disebut unit, yang terintegrasi dalam tahap berikutnya. Setiap unit dikembangkan dan diuji untuk fungsionalitas yang disebut sebagai Unit Testing.

4. Integration dan Testing

Semua unit yang dikembangkan dalam tahap implementasi diintegrasikan ke dalam sistem setelah pengujian masing-masing unit. Setelah diintegrasikan, seluruh sistem diuji untuk mengecek setiap kesalahan dan kegagalan.

5. Operation dan Maintenance

Operation dan maintenance merupakan tahapan terakhir dalam model waterfall. Software yang sudah dijalankan serta dilakukan pemeliharaan termasuk dalam memperbaiki kesalahan yang tidak ditemukan pada langkah sebelumnya.

\subsection{Desain Algoritma}

FAST (Features from Accelerated Segment Test) Corner Detection merupakan algoritma penentuan corner point yang ditemukan oleh Edward Rosten. Pada FAST Corner Detection, proses penentuan corner pointnya adalah dengan menentukan suatu titik $p$ pada koordinat $(\mathrm{x} p, \mathrm{y} p)$ pada citra dan membandingkan intensitas titik $p$ dengan empat titik di sekitarnya, dapat dilihat pada Gambar 1. Titik pertama terletak pada koordinat (x,yp-3), titik kedua terletak pada koordinat $(\mathrm{x} p+3, \mathrm{y})$, titik ketiga terletak pada koordinat ( $\mathrm{x} p-$ $3, \mathrm{y})$.

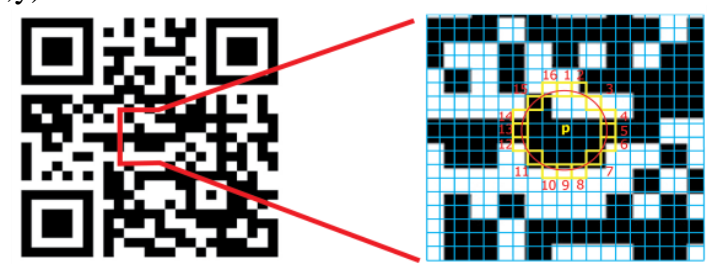

Gambar 1. Titik awal $p$ 
Jika nilai intensitas di titik $p$ bernilai lebih besar atau lebih kecil daripada intensitas sedikitnya tiga titik disekitarnya ditambah dengan suatu intensitas ambang batas (Thresshold), maka dapat dikatakan bahwa titik $p$ adalah suatu sudut. Titik $p$ akan digeser ke posisi $(\mathrm{x} p+1, \mathrm{y} p)$ dan melakukan intensitas keempat titik di sekitarnya lagi. Interaksi ini terus dilakukan sampai semua titik pada citra sudah dibandingkan.

\subsection{Software Architecture}

Arsitektur yang dibangun terdiri dari beberapa komponen yaitu, pengguna, marker, kamera. Pengguna akan menggunakan aplikasi, kemudian kamera diarahkan ke marker untuk discan, selanjutnya kamera akan melakukan tracking pada marker untuk diidentifikasi dan sistem akan melakukan render objek tiga dimensi atas marker yang telah teridentifikasi, Diagram blok arsitektur sistem ditunjukkan pada Gambar 2.

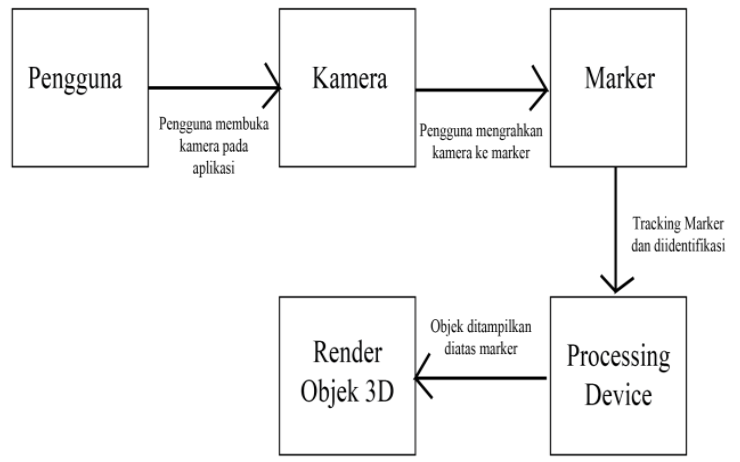

Gambar 2. Digram Blok Arsitektur Sistem

\section{$2.4 \quad$ User Interface Design}

Desain user interface terdiri atas desain marker dan model 3D.

a. Desain Marker

Desain marker yang digunakan dalam aplikasi ini adalah menggunakan QR-code yang dibuat gratis di halaman website https://keremerkan.net dan didaftarkan pada website https://developer.vuforia.com dengan file format *.jpg seperti yang ditunjukkan dalam Tabel 1.

Tabel 1. Desain Marker

\begin{tabular}{ll|l}
\hline No & $\begin{array}{c}\text { Nama } \\
\text { Marker }\end{array}$ & Gambar Marker \\
\hline 1 & Museum BI & \\
& &
\end{tabular}

2 Museum Bank Mandiri

3 Museum Fatahillah

4 Museum Seni Rupa dan Keramik

5 Museum Wayang

6 Jembatan Kota Intan
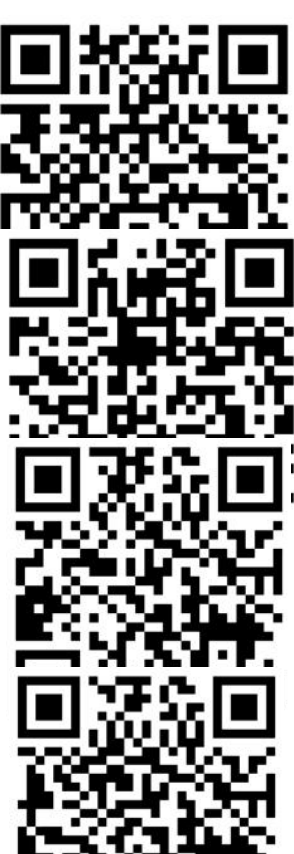

7 Cafe Batavia

8 Stasiun Jakarta Kota
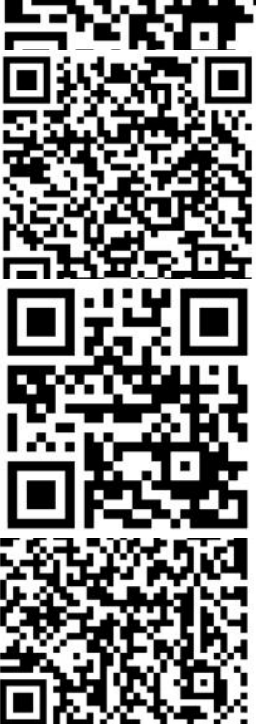

b. Model 3D

Model 3D yang digunakan dalam aplikasi ini adalah menggunakan model-model bangunan yang tersedia pada website www.3dwarehouse.sketchup.com. Model tiga dimensi yang akan digunakan pada aplikasi ini dibuat oleh akun yang bernama HMC. Model tiga dimensi dari delapan objek wisata yang ada di kawasan Kota Tua Jakarta dapat dilihat pada Tabel 2 .

Tabel 2. Model 3D

\begin{tabular}{ll|c}
\hline No & $\begin{array}{c}\text { Nama } \\
\text { Model }\end{array}$ & Model 3D \\
\hline 1 & Museum BI & \\
& &
\end{tabular}




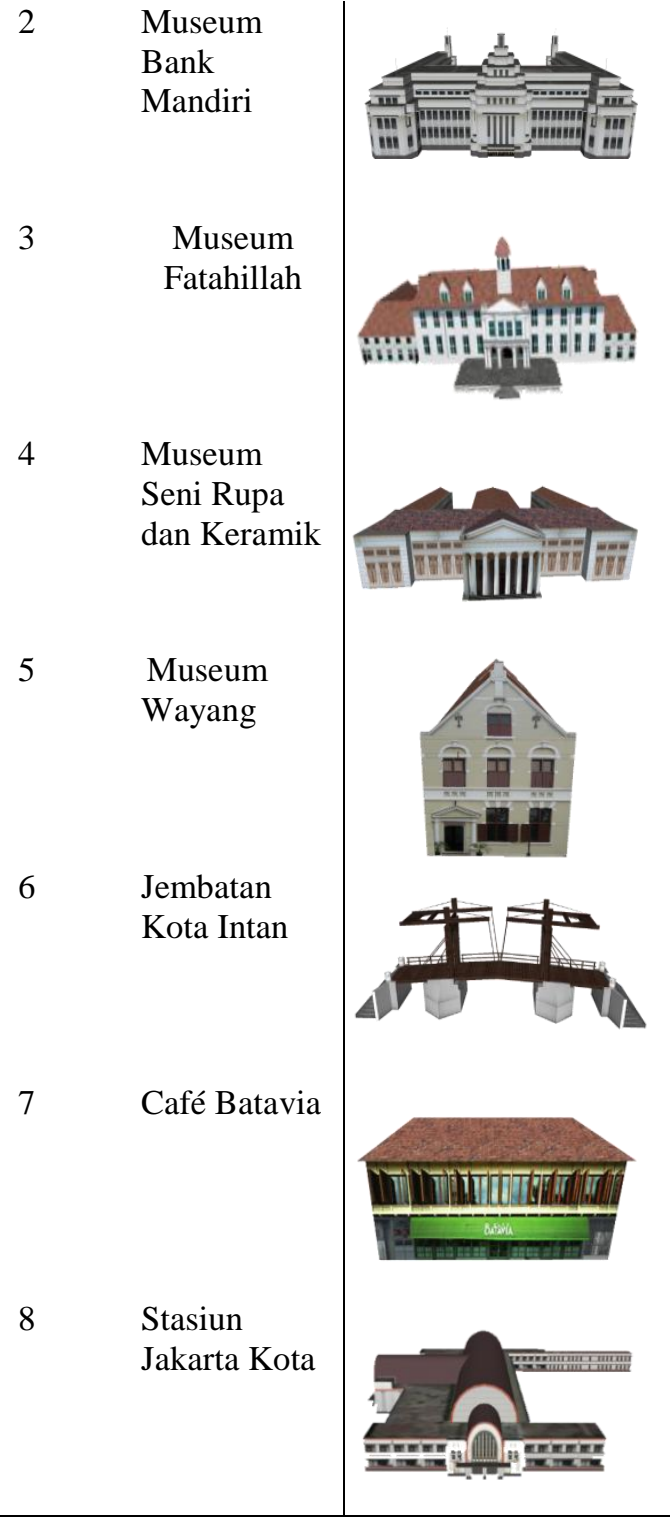

\section{PEMBAHASAN}

Hasil penelitian ini berupa aplikasi Objek Wisata Sejarah Kota Tua Jakarta yang ditampilkan dalam Gambar 3, 4, 5, 6 dan 7. Tampilan Menu utama aplikasi dapat dilihat pada Gambar 3.

a. Tampilan Menu Utama Aplikasi

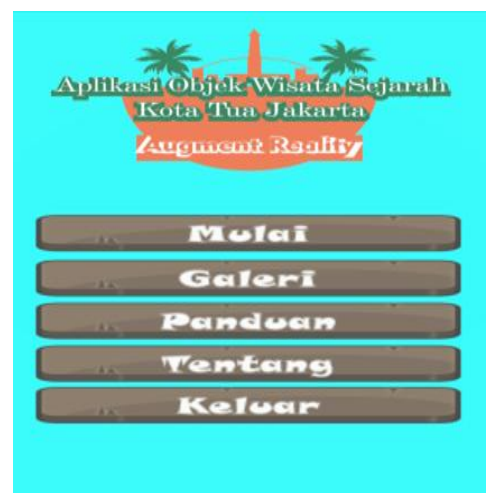

Gambar 3. Tampilan Menu Utama Aplikasi b. Tampilan scene saat marker terdeteksi, digambarkan pada Gambar 4.

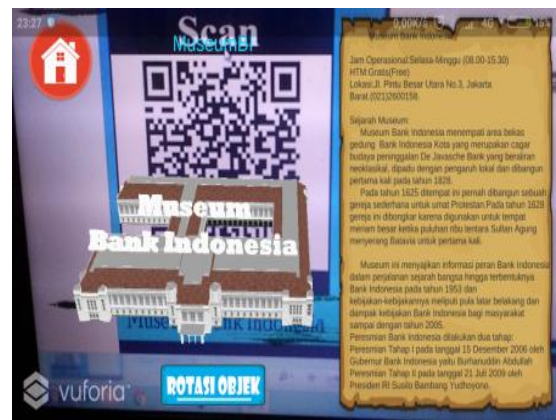

Gambar 4. Tampilan Saat Marker Terdeteksi

c. Tampilan Menu Galeri Foto, ditunjukkan pada Gambar 5.

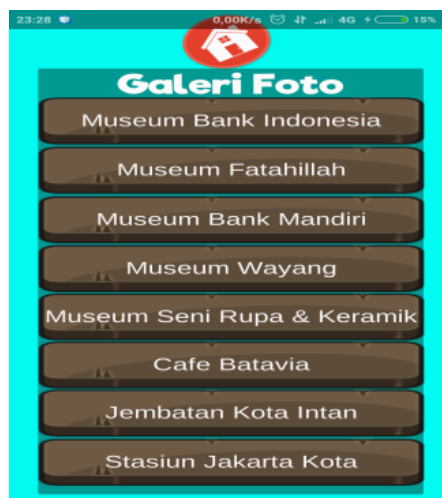

\section{Gambar 5. Tampilan Menu Galeri Foto}

d. Tampilan Menu Panduan Aplikasi. Menu Panduan atau menu Help ini tersedia juga di dalam aplikasi ditunjukkan pada Gambar 6.

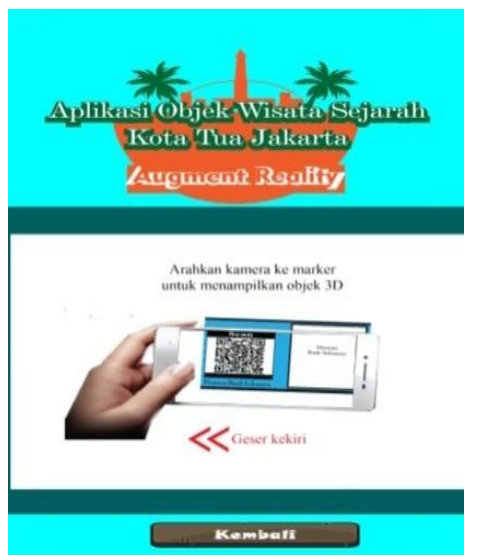

Gambar 6. Tampilan Panduan Aplikasi 
e. Tampilan Menu Keluar Aplikasi

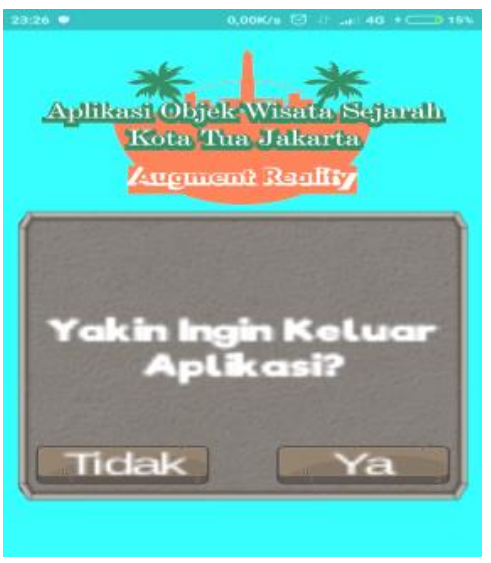

\section{Gambar 7. Tampilan Menu Keluar Aplikasi}

\subsection{Pengujian}

Pengujian dilakukan dengan metode Blackbox Testing, Pengujian Kompatibitas, dan Pengujian Marker.

1. Pengujian Black-box

Dilakukan untuk menguji validitas dari integrasi dan konsistensi sistem, hasil dari pengujian pada seluruh fungsi yang ada pada aplikasi antara input yang diberikan dan output yang dihasilkan sesuai dengan yang sudah ditentukan. Hasil yang didapat dari pengujian ini adalah semua fungsi valid.

2. Pengujian Kompatibilitas

Pengujian ini dilakukan untuk mengetahui apakah aplikasi yang telah dibuat dapat berjalan dengan baik di beberapa perangkat mobile dengan spesifikasi yang berbeda. Hasil yang didapat dari pengujian ini adalah dapat berjalan dengan baik pada tiga smartphone dengan merk, dan spesifikasi yang berbeda.

3. Pengujian Marker

Pengujian ini dilakukan untuk mengetahui kemampuan sistem dalam mendeteksi marker dan menampilkan objek tiga dimensi (3D) yang akan ditampilkan. Pengujian dilakukan dengan beberapa kondisi yaitu berdasarkan jarak dan saat marker terhalang objek lain. Hasil yang didapat pada pengujian ini adalah jarak ideal untuk memunculkan objek 3D antara marker dengan kamera smartphone adalah 6-36 cm dan persentase marker terhalang objek lain adalah $0-49 \%$.

\section{PENUTUP}

Berdasarkan hasil yang didapat dari penelitian, maka dapat disimpulkan bahwa:

1. Aplikasi pengenalan objek wisata sejarah Kota Tua dapat memudahkan pengguna dalam hal ini wisatawan yang akan berkunjung ke kawasan wisata Kota Tua.

2. Aplikasi teknologi Augment Reality juga dapat diterapkan untuk memberikan informasi atau pengenalan objek wisata berupa tiga dimensi.

3. Teknologi Augmented Reality yang diterapkan pada aplikasi yang telah dibuat dapat memberikan pengalaman yang unik untuk user atau pengguna aplikasi.

Adapun saran untuk pengembangan aplikasi selanjutnya antara lain:

1. Dapat menambahkan fitur yang dapat langsung terhubung ke aplikasi google map, bila pengguna ingin menuju ke salah satu objek wisata yang ada di kawasan Kota Tua Jakarta.

2. Dapat Marker dapat diganti dengan media lain yang lebih menarik dalam pendeteksian marker, seperti gambar objeknya langsung.

\section{PUSTAKA}

Dieck, M. C., Jung, T., Han, D., (2016). Mapping requirements for the wearable smart glasses augmented reality museum application. https://doi.org/10.1108/JHTT-09-2015-0036

Haryani, P., \& Triyono, J. (2017). Augmented Reality (AR) Sebagai Teknologi Interaktif Dalam Pengenalan Benda Cagar Budaya Kepada Masyarakat. Jurnal SIMETRIS, 8(2), 807-812.

Sikumbang, I. R. (2015). Kurangnya Informasi Objek Wisata di Jakarta. Retrieved from http://www.kompasiana.com/irwanrinaldi/kura ngnya-informasi-objek-wisata-dijakarta_5625b965109773f10b3673f5

Sinaga, E. K. (2017, December 30). 30 Persen Pengunjung Kota Tua Datang Hanya Untuk Berfoto. Tribunnews.Com. Retrieved from tribunnews.com/metropolitan/2017/12/30/30persen-pengunjung-kota-tua-hanya-datanguntuk-berfoto.

Undang-undang Republik Indonesia Tahun 2009 tentang Kepariwisataan, Pasal 1 No.5, Hal. 3, http://www.kemenpar.go.id/userfiles/file/4636 _1364-UUTentangKepariwisataannet1.pdf, diakses tanggal 20 Juli 2018. 